\title{
KEPEMILIKAN SAHAM PUBLIK DAN RETURN ON ASSETS TERHADAP PENGUNGKAPAN CORPORATE SOCIAL RESPONSIBILITY
}

\author{
Shifa Putri Hamdani \\ shifaputrihamdani@yahoo.com \\ Willy Sri Yuliandari \\ Eddy Budiono \\ Universitas Telkom
}

\begin{abstract}
The Corporate Social Responsibility (CSR) in the company recently is not only based on the single bottom line which depends only on the financial condition, but also on the triple bottom line which also depends on the financial condition, environment and society. This study aims to get empirical evidence about the influence of public ownership and Return on Assets (ROA) on the disclosure of Corporate Social Responsibility. The object of the research is a service company listed on the Indonesia Stock Exchange in 2014-2015. Collection methods used in this research is the data sourced in an annual report published by the Indonesia Stock Exchange. The collection of samples used is purposive sampling technique. Total sample of this research are 9 service companies listed in Indonesia Stock Exchange in 2014-2015. Simultaneously, public ownership and ROAgave significant effect to CSR disclosure. Partially, public ownershipgave adversely affect to the direction of CSR disclosure. ROA effect with positive direction towards CSR.
\end{abstract}

Keyword : public shareholding, return on assets (ROA), corporate social responsibility disclosure.

\begin{abstract}
Abstrak
Kegiatan Corporate Social Responsibility (CSR) yang ada dalam perusahaan tidak hanya berpaku pada single bottom line, yang lebih mengacu pada kondisi keuangan saja. Tapi bagaimana perusahaan bisa mengatur keberlanjutan secara triple bottom line, antara keuangan, lingkungan dan sosial masyarakat. Penelitian ini bertujuan untuk memperoleh bukti empiris mengenai pengaruh kepemilikan saham publik dan Return On Assets (ROA) terhadap pengungkapan Corporate Social Responsibility. Objek penelitian yang digunakan adalah perusahaan jasa yang terdaftar di Bursa Efek Indonesia Tahun 2014-2015. Metode pengumupulan data bersumber pada laporan tahunan yang dipublikasikan Bursa Efek Indonesia. Pengumpulan sampel menggunakan teknik purposive sampling. Jumlah sampel penelitian ini sebanyak 9 perusahaan jasa yang terdaftar di Bursa Efek Indonesia Tahun 2014-2015. Secara simultan kepemilikan saham publik dan ROA berpengaruh signifikan terhadap pengungkapan CSR. Secara parsial kepemilikan saham publik berpengaruh dengan arah negatif terhadap pengungkapan CSR. ROA berpengaruh dengan arah positif terhadap pengungkapan CSR.
\end{abstract}

Kata Kunci : kepemilikan saham publik, return on assets (ROA), pengungkapan corporate social responsibility. 


\section{PENDAHULUAN}

Kegiatan CSR yang ada dalam perusahaan saat ini tidak hanya berpaku pada single bottom line, yang lebih mengacu pada kondisi keuangan saja. Tapi bagaimana perusahaan bisa mengatur keberlanjutan perusahaan secara triple bottom line, antara kondisi keuangan, lingkungan dan sosial masyarakat. Jika hanya salah satu dari tiga konsep itu yang dilaksanakan perusahaan, maka perusahaan tersebut tidak akan memenuhi keberlanjutan perusahaan (Syukron, 2015).

Berbagai permasalahan Corporate Social Responsibility (CSR) di Indonesia pun bermunculan. Pada tahun 2014 Suwandi sebagai Ketua Umum Umum Corporate Forum for Community Development (CFCD) memberi penjelasan bahwa jangkauan pelaksanaan program CSR di Indonesia belum merata. Sebab, CSR ini belum dapat menjangkau seluruh lapisan masyarakat yang dilakukan hanya untuk tujuan pihak-pihak tertentu saja dan tidak bersifat berkelanjutan. Fakta lain menunjukan pelaksanaan CSR yang berpola kemitraan tidak dilakukan secara baik sejak awal. Akibatnya, pengambilan keputusan-keputusan penting dalam rangka pelaksanaan program tersebut sering dilakukan secara sepihak oleh perusahaan (www.amerta.id) tahun 2014.

Ali Darwin sebagai Chairman National Center for Sustainability Report (NSCR) mengatakan dari 438 perusahaan yang saat ini tercatat di Bursa Efek Indonesia (BEI), baru ada sekitar 25 perusahaan yang membuat laporan keberlanjutan (sustainability report). Menurut Ali ada beberapa faktor yang membuat perusahaan enggan membuat sustainability report. Pertama yaitu perusahaan tersebut tidak transparan dalam menjalankan bisnisnya, dan tidak memiliki komitmen menjadi perusahaan GCG (good corporate governance). Faktor kedua yaitu perusahaan mengganggap sustainability report sebagai sebuah biaya tambahan (www.kontan. co.id) tahun 2011. Hal ini dikaitkan dengan hasil olahan yang telah dilakukan oleh peneliti. Peneliti menemukan hanya ada 35 perusahaan dari berbagai sektor di Bursa Efek Indonesia yang menerbitkan laporan keberlanjutan sesuai dengan Global Reporting Initiative.

Selama ini pelaksanaan dan aturan CSR diatur dalam Undang-Undang yang mendukung pelaksaan CSR di Indonesia. Dalam Undang-Undang No. 40 Tahun 2007 tentang Perseroan Terbatas Pasal 74 ayat 1 yang berbunyi, "perseroan yang menjalankan kegiatan usahanya di bidang dan/atau yang berkaitan dengan sumber daya alam wajib melaksanakan tanggung jawab sosial dan lingkungan. Ketentuan ini bertujuan untuk tetap menciptakan hubungan perseroan yang serasi, seimbang, dan sesuai dengan lingkungan, nilai, norma, dan budaya masyarakat setempat. Merujuk pada Undang-Undang di atas, pengungkapan CSR bisa dimuat dalam laporan tahunan ataupun dibuat laporan secara terpisah. Laporan yang dibuat secara terpisah tersebut dinamakan sustainability report. Menurut Adam (2014) sustainability report disusun berdasarkan standar internasional. Standar internasional ini bisa digunakan berbagai sektor perusahaan di seluruh negara. Standar tersebut dikeluarkan oleh Global Reporting Initiative. Namun pada kenyataannya, hingga akhir tahun 2012, jumlah perusahaan di Indonesia yang melaporkan inisiatif keberlanjutannya dengan standar GRI (G3 atau G3.1) baru sekitar 40 (www.korantempo.com) tahun 2013.

Mardikanto (2014) menjelaskan dengan sangat jelas bahwa tanggung jawab yang lebih luas tentang Corporate Social Responsibility (CSR) tidak hanya tentang lingkungan, CSR juga tentang gagasan yang lebih luas dari etika dan keberlanjutan di tingkat pasar dan lokal. Misalnya, keberlanjutan untuk tercapainya tujuan pembangunan milenium (Millenium Development Goals/MDGs) di negara berkembang harus melampaui masalah lingkungan, sosial, dimensi lingkungan dan ekonomi di daerah lokal pertambangan, termasuk kualitas hidup, investasi sosial dalam infrastruktur masyarakat, kesehatan yang baik, perlindungan dan keamanan, dan pembangunan ekonomi dan keseimbangan modal terutama untuk masyarakat. Dalam menjalankan kegiatan bisnisnya, para pelaku bisnis selalu memperhatikan aspek lingkungan. Ini juga menjadi salah satu konsep suistanable development yang sedang dikembangkan.

Salah satu tantangan pembangunan yang berkelanjutan terdapat pada tuntutan dan pilihan serta cara berpikir serta inovatif. Pembangunan berkelanjutan bertujuan untuk memenuhi kebutuhan generasi sekarang tanpa mengurangi kemampuan pemenuhan kebutuhan bagi generasi yang akan datang (Commission on Environment and Development). Mengingat penting dan besarnya risiko terkait dengan sustainability sehingga perlu ditemukannya pilihan metode-metode pengendalian baru, terutama untuk menciptakan transparansi mengenai dampak ekonomi, lingkungan, dan sosial bagi para pemangku kepentingan. Diperlukan sebuah kerangka konsep global dengan bahasa yang konsisten dan dapat diukur dengan tujuan agar lebih jelas dan mudah dipahami. Konsep inilah yang kemudian dikenal dengan sebutan laporan keberlanjutan (sustainability report) GRI (2006).

Pedoman laporan keberlanjutan memberikan pengungkapan tentang dampak terpenting suatu 
organisasi baik positif atau negatif terhadap lingkungan, masyarakat, dan ekonomi. Dengan menggunakan pedoman keberlanjutan, organisasi pelapor dapat menghasilkan informasi andal, relevan, dan terstandardisasi yang dapat digunakan untuk menilai peluang dan risiko, serta memungkinkan pengambilan keputusan yang lebih matang, baik di dalam perusahaan maupun di antara para pemangku kepentingannya. Laporan keberlanjutan dengan menggunakan Global Reporting Initiative 4 (G4) memiliki tujuan untuk membantu menyusun laporan keberlanjutan yang mantap dan terarah menjadi praktik standar GRI 4 (2013). Tidak hanya itu laporan CSR atau laporan keberlanjutan (sustainability report) akan memberikan dampak positif dan manfaat yang lebih besar baik kepada perusahaan itu sendiri maupun para stakeholder yang terkait (www.beritadaerah.co.id) tahun 2016.

Nyatanya, perusahaan di Indonesia masih sedikit yang mengungkapkan kegiatan CSR dengan menggunakan laporan keberlanjutan sesuai pedoman GRI. Penilaian kegiatan CSR yang ada dalam perusahaan nyatanya masih belum maksimal diungkapkan. Ali Darwin, selaku ketua National Center for Sustainability Reporting (NCSR) mengatakan bahwa sistem laporan keberlanjutan belum menjadi laporan wajib di Indonesia, tetapi masih bersifat voluntary (www.ncsr-id.org) tahun 2015.

Tidak hanya mengacu pada undang-undang, tetapi juga harus mengacu pada manfaat dari CSR itu sendiri. Tanpa harus diwajibkan pun, pada dasarnya perusahaan membutuhkan CSR. Perusahaan yang sadar akan pentingnya image tak akan lagi berpikir untuk menjalankan CSR sebatas untuk memenuhi peraturan, karena salah satu manfaat utama dari CSR ialah bahwa ia berpotensi untuk menjadi solusi bagi permasalahan yang kerap terjadi dalam hubungan antara perusahaan dengan publiknya. Untuk mengatasi ketidakmampuan untuk saling memahami dan menerima serta meminimalisir sulitnya interaksi antara perusahaan dengan publiknya Mardikanto (2014).

Banyak perusahaan yang mengklaim telah melaksanakan kegiatan CSR untuk lingkungan sekitar, oleh karena itu perusahaan pun melakukan pengungkapan CSR guna untuk meningkatkan kepercayaan publik dan menjaga citra perusahaan yang tidak hanya mengejar keuntungan semata, tapi juga berorientasi pada lingkungan dan sosial. Tekanan dari pemilik saham publik selaku stakeholders, membuat manajemen perusahaan, selain mengungkapkan kinerja keuangan perusahaan, tetapi juga harus mengungkapkan informasi CSR. Hal tersebut, menunjukkan kepedulian pemilik saham publik terhadap isu-isu sosial misalnya hak asasi manusia, pendidikan, tenaga kerja, dan lingkungan sebagai isu penting untuk diungkapkan dalam laporan tahunan perusahaan Rifqiyah (2016).

Manfaat dari kegiatan CSR dilihat sisi perusahaan yaitu sebagai pelindung dan membantu perusahaan dalam meminimalkan dampak buruk yang diakibatkan oleh aktivitas perusahaan di sekitar lingkungan. Bila dilihat dari sisi stakeholders, kegiatan CSR dapat memperbaiki dan memperat hubungan perusahaan dengan para stakeholders. Manfaat inilah yang akan membuat citra perusahaan akan baik dimata masyarakat Sari (2012).

Dampak yang diberikan perusahaan untuk lingkungan masyarakat, dirasa masih kurang bahkan masih banyak yang negatif. Sudah banyak peneliti yang membuat penelitian mengenai CSR, salah satunya mengenai kepemilikan saham publik. Perusahaan yang sudah terdaftar di Bursa Efek Indonesia (BEI) berarti menandakan bahwa segala aktivitas perusahaan harus diungkapkan, karena masyarakat (public) berhak mengetahuinya dan hal ini juga sebagai bagian dari pemegang saham Rahayu dan Indah (2015).

Kepemilikan saham publik adalah proporsi saham yang dimiliki publik/masyarakat terhadap saham perusahaan. Pengertian publik disini adalah pihak individu atau institusi yang memiliki saham dibawah 5\% (<5\%) yang berada di luar manajemen dan tidak memiliki hubungan istimewa dengan perusahaan. Kelompok pemegang saham masyarakat, yaitu kelompok pemegang saham yang masing-masing memiliki kurang dari 5\% biasanya merupakan gabungan kepemilikan dari banyak masyarakat. Kelompok pemegang saham ini disebut dengan pemegang saham publik. Pemegang saham publik biasanya merupakan pemegang saham minoritas perusahaan.

Peneliti menggunakan saham publik $<5 \%$ dengan begitu bisa melihat apa CSR yang diungkapkan tinggi atau rendah. Saham yang dimiliki oleh publik mengindikasikan bahwa perusahaan tersebut memiliki kredibilitas yang tinggi pada masyarakat dalam memberikan imbalan (deviden) dan juga perusahaan mampu beroperasi terus menerus (going concern) sehingga akan melakukan pengungkapan secara luas. Hubungan antara kepemilikan saham publik dengan pengungkapan CSR menunjukan hasil bahwa semakin besar proporsi kepemilikan saham publik, semakin banyak informasi tentang perusahaan, dan semakin banyak butir yang diungkapkan pada laporan tahunan serta semakin luas pula pengungkapan tanggung jawab sosialnya A'inun Na'im dan Fuad Rakhman (2005).

Penelitian yang dilakukan oleh Rita (2013) mengatakan bahwa kepemilikan saham publik berpengaruh positif namun tidak signifikan terhadap 
pengungkapan CSR. Hasil penelitian yang dilakukan oleh Putra (2011) menunjukan bahwa kepemilikan saham publik berpengaruh terhadap pengungkapan CSR. Berbeda dengan hasil penelitian yang didapat oleh Bajuri (2007), serta Wakidi dan Hasan (2011) yang menunjukkan bahwa kepemilikan saham publik tidak berpengaruh terhadap pengungkapan CSR. Sudah banyak penelitian terdahulu yang melakukan penelitian terkait pengungkapan Corporate Social Responsibility (CSR), namun peneliti satu dengan peneliti lain memiliki keragaman hasil. Hal ini disebabkan oleh karakteristik yang dimiliki perusahaan berbeda.

Sama halnya dengan Putra (2011), Nur dan Denies (2012) menunjukan hasil kepemilikan saham publik tidak berpengaruh terhadap pengungkapan CSR. Seperti penelitian yang dilakukan oleh Sriayu dan Mimba (2013) menyatakan bahwa kepemilikan saham publik menunjukan hasil positif dan signifikan. Indraswari dan Ida (2015) menunjukan hasil bahwa kepemilikan saham publik berpengaruh negatif terhadap pengungkapan CSR perusahaan.

Rasio profitabilitas merupakan rasio yang digunakan untuk mengukur kemampuan perusahaan dalam menghasilkan laba dari aktivitas normal bisnisnya. Rasio ini pun bertujuan untuk mengukur tingkat efektifitas manajemen dalam menjalankan operasional perusahaan (Hery, 2016: 192). Semakin tinggi hasil pengembalian atas aset berarti semakin tinggi pula jumlah laba bersih yang dihasilkan dari setiap rupiah dana yang tertanam dalam total aset. Begitu juga sebaliknya(Hery, 2016:193). Hubungan antara profitabilitas menggunakan proksi return on assets (ROA) menunjukan jika tingkat ROA tinggi maka pengungkapan CSR pun akan tinggi, karena perusahaan akan semakin luas untuk mengungkapkan tanggung jawab sosialnya.

Penelitian yang dilakukan oleh Kamil dan Herusetya (2012) menunjukan bahwa profitabilitas yang tinggi akan mendorong pengungkapan CSR yang tinggi juga, ini disebabkan oleh meningkatnya jumlah laba perusahaan, maka perusahaan pun semakin luas dalam mengungkapkan tanggung jawab sosialnya. Penelitian yang dilakukan oleh Sari (2012) mengenai profitabilitas dan hasilnya positif terhadap pengungkapan CSR. Penelitian Vintila dan Florinita (2013) berhasil menunjukan profitabilitas dengan hasil positif terhadap pengungkapan CSR. Pradnyani dan Eka (2015) mengatakan bahwa profitabilitas berpengaruh terhadap pengungkapan CSR dimana profitabilitas mampu memenuhi kebutuhan manajemen untuk mengungkapkan CSR. Namun, ada beberapa penelitian yang berbeda dengan Kamil dan Herusetya, seperti yang dilakukan oleh Sembiring (2005) mengatakan bahwa tidak ada pengaruh profitabilitas terhadap pengungkapan tanggung jawab sosial perusahaan. Nur dan Denies (2012) juga mengatakan bahwa profitabilitas tidak berpengaruh terhadap pengungkapan CSR.

Permasalahan mengenai pengungkapan CSR tersebut yang dijelaskan diatas dapat disimpulkan bahwa masih banyak perusahaan yang belum mengungkapkan laporan CSR nya. Beberapa penelitian terdahulu yang sudah ditunjukan di atas pun menunjukkan hasil yang masih belum konsisten sehingga membuat penulis ingin melakukan penelitian lebih lanjut mengenai pengungkapan Corporate Social Responsibility.

Penelitian ini menggunakan perusahaan jasa yang terdaftar di Bursa Efek Indonesia tahun 2014-2015 sebagai populasi karena perusahaan-perusahaan tersebut banyak melakukan pengungkapan CSR dibanding sektor utama dan manufaktur. Tujuan penelitian ini adalah untuk menguji pengaruh kepemilikan saham publik dan Return On Assets terhadap pengungkapan corporate social responsibility pada perusahaan jasa yang terdaftar di Bursa Efek Indonesia pada tahun 2014-2015.

Kepemilikan saham publik (public shareholding) adalah proporsi kepemilikan saham yang dimiliki oleh publik atau masyarakat terhadap saham perusahaan. Pengertian publik disini adalah pihak individu atau institusi yang memiliki saham dibawah $5 \%(<5 \%)$ yang berada di luar manajemen dan tidak memiliki hubungan istimewa dengan perusahaan Rifqiyah (2016).

Semakin besar kepemilikan yang dimiliki oleh publik, maka publik pun ingin mengetahui mengenai informasi tentang perusahaan sehingga makin banyak butir yang diungkapkan melalui laporan keuangan. Investor ingin memperoleh informasi yang luas tentang tempat mereka berinvestasi serta dapat mengawasi kegiatan manajemen agar kepentingan perusahaan terpenuhi A'inun Na'im dan Fuad Rakhman (2005).

Perusahaan yang dikelola dengan baik akan terlihat dari kinerja keuangan perusahaan yang bisa dilihat dari jumlah penjualan, tenaga kerja, asset yang dimiliki dan analisis rasio yang disajikan dalam laporan keuangan Dipraja (2014). Selain itu, ROA memberikan ukuran yang lebih baik atas profitabilitas perusahaan karena menunjukan efektivitas manajemen dalam menggunakan aktiva untuk memperoleh pendapatan. Maka dari itu peneliti menggunakan ROA sebagai variabel penelitian

Perusahaan mendapatkan laba akan memberikan kebebasan kepada manajemen untuk melakukan CSR yang juga merupakan langkah untuk menjaga korelasi baik dengan stakeholders Pradnyani dan Eka (2015). Semakin tinggi profitabilitas dengan menggunakan proksi ROA perusahaan maka pengungkapan tanggung jawab sosial pun semakin tinggi juga. Hal ini menggambarkan kemampuan perusahaan dalam menghasilkan laba yang tinggi, sehingga perusahaan mampu meningkatkan tanggung jawab sosial serta 
melakukan pengungkapan tanggung jawab sosialnya lebih luas Kamil dan Herusetya (2012).

Paradigma Penelitian ditunjukkan pada Gambar 1. Hipotesis yang diajukan :

1. Kepemilikan Saham Publik berpengaruh positif terhadap Pengungkapan Corporate Social Responsibility.

2. Return On Assets (ROA) berpengaruh positif terhadap Pengungkapan Corporate Social Responsibility.

\section{METODE}

Penelitian ini menggunakan metode kuantitatif dengan deskriptif verifikatif bersifat kausalitas. Operasionalisasi Variabel ditunjukkan pada Tabel 1. Populasi dalam penelitian adalah perusahaan jasa yang terdaftar di Bursa Efek Indonesia tahun 2014-2015. Sampel dalam penelitian ini ditentukan dengan teknik purposive sampling, yaitu teknik pengambilan sampel dengan kriteria tertentu yang ditunjukkan pada Tabel 2.

Tabel 1. Operasionalisasi Variabel

\begin{tabular}{|c|c|c|c|c|}
\hline \multicolumn{5}{|c|}{ Variabel Independen } \\
\hline Variabel & Konsep variabel & Indikato & & Skala \\
\hline \multirow[t]{2}{*}{$\begin{array}{l}\text { Kepemilikan } \\
\text { Saham Publik }\end{array}$} & \multirow{2}{*}{$\begin{array}{l}\text { kepemilikan saham publik (public share- } \\
\text { holding) adalah proporsi kepemilikan } \\
\text { saham yang dimiliki oleh publik atau } \\
\text { masyarakat terhadap saham perusahaan } \\
\text { (Rifqiyah, 2016) }\end{array}$} & \multirow{2}{*}{$\mathrm{KSP}=$} & $\begin{array}{l}\text { Kepemilikan Saham Publik } \\
<5 \%\end{array}$ & \multirow[t]{2}{*}{ Rasio } \\
\hline & & & $\begin{array}{l}\text { Total lembar saham } \\
\text { perusahaan }\end{array}$ & \\
\hline \multirow{2}{*}{$\begin{array}{l}\text { Return On } \\
\text { Assets (ROA) } \\
\left(\mathrm{X}_{2}\right)\end{array}$} & \multirow{2}{*}{$\begin{array}{l}\text { rasio yang menunjukan hasil (return) atas } \\
\text { jumlah aktiva yang digunakan dalam } \\
\text { perusahaan (Kasmir, 2012) }\end{array}$} & \multirow{2}{*}{$\mathrm{ROA}=$} & Net Income & \multirow[t]{2}{*}{ Rasio } \\
\hline & & & Total Asset & \\
\hline \multicolumn{5}{|c|}{ Variable Dependen } \\
\hline Variabel & Konsep variabel & Indikato & & Skala \\
\hline \multirow{5}{*}{$\begin{array}{l}\text { Pengungka- } \\
\text { pan Corpo- } \\
\text { rate Social } \\
\text { Responsibility } \\
\text { (Y) }\end{array}$} & \multirow{5}{*}{$\begin{array}{l}\text { Komitmen bisnis untuk berkontribusi } \\
\text { terhadap pembangunan ekonomi yang } \\
\text { berkelanjutan, bekerja dengan karyawan, } \\
\text { keluarga mereka dan masyarakat lokal } \\
\text { (WBCSD, 2001) }\end{array}$} & \multirow{2}{*}{\multicolumn{2}{|c|}{$\mathrm{CSRI}_{\mathrm{j}}=\frac{\sum \mathrm{X}_{\mathrm{ii}}}{\mathrm{n}_{\mathrm{j}}}$}} & \multirow[t]{5}{*}{ Rasio } \\
\hline & & & & \\
\hline & & \multicolumn{2}{|c|}{$\begin{array}{l}\text { CSRI : Corporate Social Responsibility Index } \\
\text { perusahaan } j\end{array}$} & \\
\hline & & \multicolumn{2}{|c|}{$\mathrm{n}_{\mathrm{j}}$ j jumlah item untuk perusahaan $\mathrm{j}$. } & \\
\hline & & \multicolumn{2}{|c|}{$\begin{array}{l}X_{i}: 1 \text { jika item i diungkapkan; } 0 \text { jika item I tidak } \\
\text { diungkapkan. Dengan demikian, } 0 \leq \mathrm{CSRlj} \leq 1 \text {. }\end{array}$} & \\
\hline
\end{tabular}

Sumber: data diolah (2017)

Tabel 2. Kriteria Sampel

\begin{tabular}{lc}
\hline \multicolumn{1}{c}{ Kriteria Pengambilan Sampel } & Jumlah \\
\hline $\begin{array}{l}\text { Perusahaan jasa terdaftar di Bursa Efek Indonesi } \\
\text { periode 2014-2015. }\end{array}$ & 316 \\
$\begin{array}{l}\text { Perusahaan sampel yang tidak menerbitkan laporan } \\
\text { CSR }\end{array}$ & $(293)$ \\
$\begin{array}{l}\text { Perusahaan sampel yang tidak menerbitkan lapo- } \\
\text { ran CSR sesuai Global Reporting Initiative 4 (G4) }\end{array}$ & $(4)$ \\
Perusahaan jasa sektor bank & $(10)$ \\
Jumlah sampel yang dijadikan objek penelitian & 9 \\
Jumlah data periode 2014-2015 & 18 \\
\hline Sum : dat dioan
\end{tabular}

Sumber : data dioah oleh penulis (2017)

Berdasarkan Tabel tersebut dihasilkan sampel penelitian sebanyak 9 perusahaan. Teknik analisis yang digunakan dalam penelitian ini menggunakan analisis statistik deskriptif dan model regresi data panel.
HASIL

Hasil perhitungan statistik deskriptifmenggunakan Eviews 8.0 ditunjukkan pada Tabel 2 .

Tabel 3. Hasil Pengujian Statistik Deskriptif

\begin{tabular}{lllll}
\hline & KSP & ROA & CSR & Observation \\
\hline Mean & $35.33 \%$ & $4.00 \%$ & $29.46 \%$ & 18 \\
Maximun & $47.45 \%$ & $15.22 \%$ & $57.00 \%$ & 18 \\
Minimun & $13.55 \%$ & $-12.00 \%$ & $10.00 \%$ & 18 \\
Std. Dev & $9.36 \%$ & $6.48 \%$ & $13.45 \%$ & 18 \\
\hline
\end{tabular}

Sumber : data diolah penulis (2017)

Rata-rata Kepemilikan Saham Publik sebesar $35.33 \%$ berada di atas standar deviasinya yaitu sebesar 9.36\%. Berarti data variabel kepemilikan 
saham publik tidak bervariasi, sehingga apabila ditarik garis lurus pada titik-titik tersebut akan saling berhubungan dan membentuk satu garis lurus. Perusahaan dengan kepemilikan saham publik di atas rata-rata disebabkan karena perusahaan ingin lebih memberikan informasi yang seluasluasnya kepada investor sebelum berinvestasi tidak hanya berpaku pada laporan keuangan tetapi bisa mempertimbangkan laporan keberlanjutan sebagai bentuk tanggung jawab perusahaan terhadap lingkungan, sosial, dan ekonomi. Sedangkan perusahaan dengan nilai di bawah rata-rata bisa disebabkan kecilnya nilai saham yang dimiliki oleh publik akan berbanding terbalik dengan jumlah saham yang beredar membuat kepemilikan saham publik berada dibawah nilai rata-rata.

Berdasarkan Tabel 3 rata-rata Return On Assets (ROA) sebesar $4,00 \%$ dengan standar deviasinya yaitu sebesar $6,48 \%$. Dari data tersebut menunjukkan bahwa data ROA bervariasi, karena nilai standar deviasi lebih besar dari nilai rata-rata. Artinya, data tersebut tidak berkelompok atau menyebar, sehingga apabila ditarik garis lurus pada titik tersebut akan saling bersimpangan dan tidak membentuk satu garis lurus.

Berdasarkan Tabel 3 rata-rata pengungkapan CSR dari tahun 2014-2015 sebesar 29,46\% berada di atas standar deviasinya yaitu sebesar 13,45\%, artinya data berkelompok, sehingga apabila ditarik garis lurus pada titik-titik tersebut akan saling berhubungan dan membentuk satu garis lurus.

Tabel 4. Hasil Uji Chow

Redundant Fixed Effects Tests

Equation: Untitled

Test cross-section fixed effects

\begin{tabular}{lccc}
\hline Effect Test & Statistic & d.f. & Prob. \\
\hline Cross-section F & 1.953377 & $(8,7)$ & 0.1965 \\
$\begin{array}{l}\text { Cross-section } \\
\text { Chi-square }\end{array}$ & 21.118218 & 8 & 0.0068 \\
\hline
\end{tabular}

Sumber :data diolah penulis (2017)

Berdasarkan hasil uji chow (Tabel 4) model yang dapat digunakan adalah common effect, tetapi keputusan penggunaan model ini belum merupakan hasil akhir karena harus melihat Uji Lagrange Multiplier terlebih dahulu.

Berdasarkan Tabel 5, hasil uji Lagrange Multiplier menunjukkan bahwa nilai cross-section Breusch-Pagan sebesar 0.2688 atau lebih besar dari taraf signifikasi 5\%. Menyatakan bahwa model common effect lebih baik daripada model random effect. Berdasarkan kedua uji tersebut, maka model regresi data panel yang sesuai untuk penelitian ini adalah model common effect.

Tabel 5. Uji Signifikansi Lagrange Multiplier Lagrange multiplier (LM) test for panel data

Date: 03/15/17 Time: 15:03

Sample: 20142015

Total panel observations: 18

Probability in ()

\begin{tabular}{llll}
\hline $\begin{array}{l}\text { Null (no } \\
\text { rand. effect) } \\
\text { Alternative }\end{array}$ & $\begin{array}{l}\text { Cross- } \\
\text { section One- } \\
\text { sided }\end{array}$ & $\begin{array}{l}\text { Period One- } \\
\text { sided }\end{array}$ & Both \\
\hline Breusch- & 1.222872 & 0.876828 & 2.099699 \\
Pagan & $(0.2688)$ & $(0.3491)$ & $(0.1473)$ \\
Honda & 1.105835 & -0.936391 & 0.119815 \\
& $(0.1344)$ & $(0.8255)$ & $(0.4523)$ \\
King-Wu & 1.105835 & -0.936391 & -0.514226 \\
& $(0.1344)$ & $(0.8255)$ & $(0.6965)$ \\
GHM & -- & -- & 1.222872 \\
& -- & -- & $(0.2700)$ \\
\hline
\end{tabular}

Sumber :data diolah penulis (2017)

Tabel 6. Hasil Uji F (Simultan) Weighted Statistics

\begin{tabular}{lclc}
\hline R-squared & 0.981157 & $\begin{array}{l}\text { Mean } \\
\text { dependent var }\end{array}$ & 113.3426 \\
$\begin{array}{l}\text { Adjusted } \\
\text { R-squared }\end{array}$ & 0.978645 & $\begin{array}{l}\text { S.D. dependent } \\
\text { var }\end{array}$ & 202.5843 \\
$\begin{array}{l}\text { S.E. of } \\
\text { regression }\end{array}$ & 9.117527 & $\begin{array}{l}\text { Sum squared } \\
\text { resid }\end{array}$ & 1246.939 \\
$\begin{array}{l}\text { F-statistic } \\
\text { S90.5292 }\end{array}$ & $\begin{array}{l}\text { Durbin-Watson } \\
\text { stat }\end{array}$ & 2.309478 \\
$\begin{array}{l}\text { Prob } \\
\text { (F-statistic) }\end{array}$ & 0.000000 & & 0.000000 \\
\hline Sumber: Data yang diolah (2017) &
\end{tabular}

Berdasarkan Tabel 6, nilai adjusted R-squared sebesar 0.978645. Hal ini menunjukkan bahwa Kepemilikan Saham Publik dan ROA berpengaruh signifikan terhadap pengungkapan CSR sebesar $97.86 \%$, sedangkan sisanya $2.14 \%$ dijelaskan oleh variabel lain di luar penelitian.

Tabel 7. Hasil Uji T-Parsial

\begin{tabular}{lllll}
\hline Variable & Coefficient & Std. Error & t-Statistic & Prob. \\
\hline KSP & -0.279965 & 0.044116 & -6.346139 & 0.0000 \\
ROA & 1.975025 & 0.078345 & 25.20947 & 0.0000 \\
C & 28.25696 & 1.093386 & 25.84355 & 0.0000 \\
\hline
\end{tabular}

Sumber: Data yang diolah (2017) 
Berdasarkan Tabel 7, diperoleh persamaan sebagai berikut:

Pengungkapan CSR $=28,25696-0,279965 \mathrm{KSP}+$ $1,975025 \mathrm{ROA}+\varepsilon$

\section{PEMBAHASAN}

Nilai maksimum Kepemilikan Saham Publik dimiliki oleh PT Telkom Tbk sebesar 47,44\% tahun 2014 dan sebesar 47,45\% di tahun 2015. Nilai minimum Kepemilikan Saham Publik dimiliki $13,55 \%$ tahun 2014 dan saham publik $14,90 \%$ di tahun 2015. Nilai minimum didorong oleh saham yang besar dikendalikan oleh negara Republik Indonesia sebesar 60,50\%, Credit Suisse AG Singapore TR AC CL PT Trans Airways sebesar 25,90\% sisanya hanya $13,55 \%$ dimiliki oleh publik.

Nilai maksimum dari rasio ROA dilihat dari tahun 2014 dan 2015 dimiliki oleh PT Telkom Tbk sebesar 14,03\%, dengan jumlah laba bersih sebesar $\mathrm{Rp}$ 23.317.000.000.000 dan total aset sebesar Rp 166.173.000.000.000. Hal ini disebabkan karena PT Telkom Tbk meneruskan tiga program utama yang telah dicanangkan sejak dua tahun sebelumnya guna mempertahankan pertumbuhan double digit Telkomsel, mendorong bisnis digital network, serta mengembangkan dan memperluas bisnis internasional. Nilai minimum untuk rasio ROA tahun 2014 dimiliki oleh PT Garuda Indonesia Tbk. ROA senilai $-12,00 \%$ muncul karena PT Garuda Indonesia Tbk mengalami rugi akibat jumlah beban lebih besar dari pendapatan, dan juga harus dikurangi lagi dengan beban pajak. Nilai minimum untuk rasio ROA tahun 2015 dimiliki oleh perusahaan PT Indika Energi Tbk nilai dengan nilai ROA sebesar $-3,57 \%$. Nilai minimal terjadi karena adanya penurunan laba tahun berjalan karena dampak krisis di Uni Eropa, China, dan India. Secara umum, harga komoditas pertambangan utama dunia termasuk batubara mengalami penurunan.

Nilai maksimum pengungkapan CSR tahun 2014 sebesar 48,00\% dimiliki oleh PT Garuda Indonesia Tbk yaitu mengungkapkan 44 item dari 91 item yang terdapat di Global Reporting Initiative 4 (G4). Hal ini disebabkan karena dengan adanya laporan keberlanjutan merupakan langkah awal Garuda Indonesia dalam menciptakan roda bisnis yang mampu memberikan manfaat berkesinambungan bagi seluruh kepentingan. Mengacu pada tiga pilar utama yaitu, sumber daya manusia (people), manfaat ekonomis (profit), dan kelestarian lingkungan (planet). Seperti mata rantai yang tidak dapat dipisahkan, tiga pilar utama di atas merupakan akar utama dari bisnis yang berkelanjutan. Nilai maksimum pengungkapan CSR tahun 2015 dimiliki oleh PT AKR Corporindo Tbk sebesar 57,00\%. Itemitem yang diungkapkan sebanyak 52 dari 91 item. Posisi PT AKR Corporindo Tbk sebagai perusahaan penyedia solusi supply chain terpadu di Indonesia dalam distribusi bahan bakar minyak (BBM) dan bahan kimia dasar, jasa logistik, pembuatan sorbitol, dan bahan perekat, pabrikan serta kawasan industri dan pelabuhan terintegrasi kian kokoh. Perseroan menunjukan kinerja terbaik dengan peningkatan laba. Keberhasilan itu ditopang oleh iklim dan lingkungan kerja yang mengedepankan keselamatan dan kesehatan kerja sehingga mencapai kecelakaan nihil (zero accident).

Nilai minimum untuk pengungkapan CSR tahun 2014 dimiliki oleh PT Indika Energi Tbk mengungkapkan item dalam laporan keberlanjutan sebesar $11,00 \%$ dan menurun menjadi $10,00 \%$ di tahun 2015. PT Indika Energi Tbk tahun 2014 hanya mengungkapkan CSR 10 dari 91 item dan mengalami penurunan.

Pada Tabel 7, Kepemilikan Saham Publik (KSP) berpengaruh signifikan terhadap pengungkapan CSR. Hasil tersebut tidak mendukung hipotesis yang dikemukakan karena arah yang dihasilkan negatif. Nilai koefisien regresi negatif sebesar $-0,279965$ artinya semakin tinggi kepemilikan saham publik tidak menjamin pengungkapan CSR rendah. Hal ini diperkuat dengan Tabel 3 pada statistik deskriptif bahwa perusahaan yang memiliki saham publik terendah yaitu PT. Garuda Indonesia Tbk tahun 2014 dengani nilai $13,55 \%$ tetapi memiliki nilai maksimum dalam pengungkapan CSR sebesar 48,00\%. Alasan yang dapat digunakan untuk menjelaskan penelitian ini adalah karena saham publik dengan proporsi $<5 \%$ membuat perusahaan gencar untuk meningkatkan perusahaannya dengan cara menerbitkan laporan keberlanjutan. Ini dimaksudkan agar investor tertarik untuk menanamkan sahamnya di perusahaan tersebut.

Hal lainnya juga disebabkan karena kurangnya perhatian perusahaan terhadap saham publik, maka dari itu investor menganggap dengan adanya CSR dan perusahaan melakukan pengungkapan CSR tersebut akan menumbuhkan minat investor untuk menambah saham publiknya. Hasil penelitian ini sejalan dengan hasil penelitian yang telah dilakukan oleh Rahayu dan Indah (2015) bahwa kepemilikan saham publik berpengaruh dengan arah negatif terhadap pengungkapan CSR.

Return On Assets (ROA) berpengaruh signifikan terhadap pengungkapan CSR. Nilai koefisien regresi positif artinya, ketika ROA semakin tinggi maka pengungkapan CSR pun akan tinggi, karena perusahaan akan semakin luas untuk mengungkapkan tanggung jawab sosialnya.

ROA juga menunjukkan laba perusahaan dengan membagi laba bersih terhadap total aktiva 
yang dimiliki perusahaan sehingga rasio ini disebut juga dengan earning power karena menurut hasil penelitian yang dilakukan oleh Pradnyani dan Eka (2015) bahwa profitabilitas berpengaruh terhadap pengungkapan CSR dimana profitabilitas mampu memenuhi kebutuhan manajemen untuk mengungkapkan CSR. Penelitian ini sejalan dengan penelitian yang dilakukan oleh Indraswari dan Ida (2015) menunjukan bahwa ROA berpegaruh positif terhadap pengungkapan CSR.

\section{KESIMPULAN}

Berdasarkan hasil penelitian dan pembahasan, dapat ditarik kesimpulan sebagai berikut.

1. Berdasakan pengujian analisis statistik deskriptif;

(a.) Rata-rata kepemilikan saham publik pada perusahaan jasa non bank tahun 2014-2015 sebesar $34,42 \%$. Nilai maksimum dimiliki PT. Telkom Tbk. Nilai minimum pada tahun 2015 dimiliki PT. Garuda Indonesia Tbk. (b.) R a t a rata Return On Assets (ROA) pada perusahaan jasa non bank tahun 2014-2015 sebesar 4,04\%. Nilai maksimum tahun 2014 dan 2015 dimiliki PT. Telkom Tbk, dan minimum tahun 2014 dimiliki PT. Garuda Indonesia Tbk serta PT. Indika Energi Tbk pada tahun 2015. (c.) Rata-rata Pengungkapan Corporate Social Responsibility pada perusahaan jasa non bank tahun 2014-2015 sebesar 26,47\%. Nilai maksimum pada tahun 2015 adalah PT. AKR Corporindo Tbk. Nilai minimum pada tahun 2015 adalah PT. Indika Energi Tbk.

2. Berdasarkan pengujian hipotesis secara simultan Kepemilikan Saham Publik (KSP) dan Return On Assets (ROA) berpengaruh signifikan dengan terhadap Pengungkapan Corporate Social Responsibility pada perusahaan jasa non bank yang terdaftar di Bursa Efek Indonesia tahun 2014-2015.

3. Kepemilikan Saham Publik berpengaruh signifikan negatif terhadap Pengungkapan Corporate Social Responsibility. Return On Assets (ROA) berpengaruh signifikan positif terhadap Pengungkapan Corporate Social Responsibility perusahaan jasa non bank yang terdaftar di Bursa Efek Indonesia tahun 2014-2015.

\section{DAFTAR PUSTAKA}

Ainun Na'im dan Fuad Rakhman. 2000. Analisis Hubungan Antara Kelengkapan Pengungkapan Laporan Keuangan dengan Struktur Modal dan Tipe Kepemilikan Perusahaan. Jurnal Riset Akuntansi Indonesia, 15, BPFE UGM, Yogyakarta.

Badjuri, Achmad. 2011. Faktor-Faktor Fundamental, Mekanisme Corporate.
Dipraja, Ibnu. 2014. Pengaruh Corporate Social Responsibility Terhadap Kinerja Keuangan (Studi Empiris pada Perusahaan Manufaktur yang Terdaftar di BEI periode 2010-2012. Jurnal Akuntansi Fakultas Ekonomika dan Bisnis Universitas Dian Nuswantara Hal 1-17.

Hery. 2016. Analisis Laporan Keuangan Integrated and Comprehensive Edition. Jakarta: Grasindo.

Indraswari, Gusti Ayu Dyah dan Ida, Bagus Putra Astika. 2015. Pengaruh Profitabilitas, Ukuran Perusahaan, dan Kepemilikan Saham Publik Terhadap Pengungkapan CSR. E-jurnal Akuntansi Universitas Udayana 289-302.

Kamil, Ahmad dan Antonius Herusetya. 2012. Pengaruh Karakteristik Perusahaan Terhadap Luas Pengungkapan Kegiatan Corporate Social Responsibility. Media Riset Akuntansi, Vol.2,No.1.

Kasmir. 2012. Analisis Laporan Keuangan. Jakarta: Raja Grafindo Persada.

Kristi, Agatha Aprinda. 2013. Faktor-Faktor Yang Mepengaruhi Pengungkapan Corporate Social Responsibility Pada Perusahaan Publik Di Indonesia. Vol 1, No 1: Semester Ganjil 2012/2013 - S1 Akuntansi.

Mardikanto, Totok. 2014. CSR (Corporate Social Responsibility) (Tanggung jawab sosial korporasi). Bandung: Alfabeta.

Nurkhin, Akhmad. 2010. Corporate Governance dan Profitabilitas, Pengaruhnya Terhadap Pengungkapan

CSR Sosial Perusahaan. Jurnal Dinamika Akuntansi, Vol 2 No.1. Hal 46-55.

Nur, Marzully dan Denies, Priantinah. 2012. Analisis Faktor-Faktor yang Mempengaruhi Pengungkapan Corporate Social Responsibility di Indonesia (Studi Empiris Pada Perusahaan Berkategori High Profile yang Listing di Bursa Efek Indonesia). Jurnal Nominal Vol. 1 No. 1

Pradnyani, I Gusti Agung Arista, dan Eka Ardhani Sisdyani. 2015. Pengaruh Ukuran Perusahaan, Profitabilitas, Leverage, dan Ukuran Dewan Komisaris Pada Pengungkapan Tanggung Jawab Sosial Perusahaan. E-jurnal Akuntansi Universitas Udayana 326-344.

Putra, Eka Nanda dan Rahardjo, Shiddiq Nur. 2011. Pengaruh Karakteristik Perusahaan Terhadap Pengungkapan Corporate Social Responsibility (CSR).

Rahayu, Puji dan Indah, Anisyukurillah. 2015. Pengaruh Kepemilikan Saham Publik, Profitabilitas, dan Media Terhadap Pengungkapan Tanggung Jawab Sosial. Accounting Analysis Journal, ISSN 2252-6765.

Rifqiyah, Rina Fatkhiyatur. 2016. Pengaruh Profitabilitas, Ukuran Perusahaan, dan Kepemilikan Saham Publik Terhadap Pengungkapan Corporate Social Responsibility (CSR). Artikel Ilmiah. 
Rita, Maria Rio dan Sartika. 2013. Pengaruh Profitabilitas dan Kepemilikan Saham Publik Terhadap Luas Pengungkapan Corporate Social Responsibility (CSR).

Sari, Rizkia Anggita. 2012. Pengaruh Karakteristik Perusahaan Terhadap Corporate Social Responsibility Disclosure Pada Perusahaan Manufaktur Yang Terdaftar di Bursa Efek Indonesia. Jurnal Nominal, Vol. 1, No.1.

Sembiring, Eddy Rismanda. 2005. Karakterstik Perusahaan dan Pengungkapan Tanggung Jawab Sosial: Studi Empiris Pada Perusahaan yang Tercatat di Bursa Efek Jakarta. SNA VIII Solo, 15-16 September 2005.

Sriayu, Gusti Ayu Putu Wiwik dan Mimba, Ni Putu Sri
Harta. 2013. Pengaruh Karakteristik Perusahaan Terhadap Corporate Social Responsibility Disclosure. E-jurnal Akuntansi Universitas Udayana ISSN 2302-8556.

Undang-Undang Republik Indonesia No. 40 Tahun 2007 tentang Perseroan Terbatas.

Vintila, Georgeta dan Florinita Duca. 2013. A Study of the Relationship between Corporate Social Responsibility- Financial Performance- Firm Size.

Wakidi, Rivi Hamdani dan Hasan, Sakti Siregar. 2011. Pengaruh Sisi Internal dan Eksternal Perusahan Terhadap Pengungkapan Tanggung Jawab Sosial Pada Perusahaan Manufaktur Yang Terdaftar di BEI. Jurnal Ekonom, Vol 14, No.4.

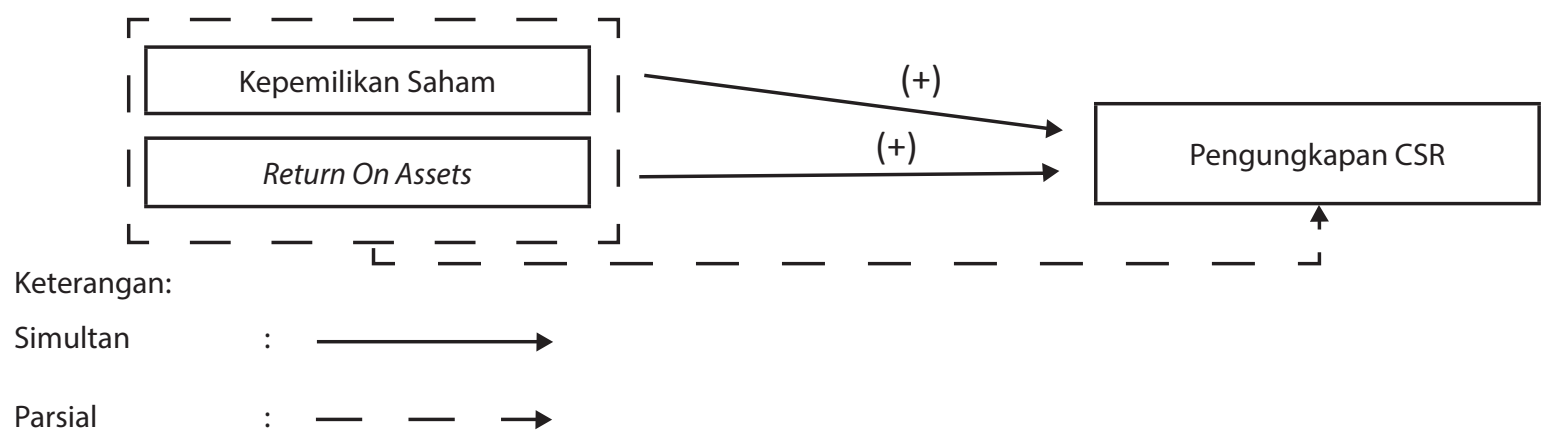

Gambar 1. Paradigma Penelitian 